\title{
Effect of Supplementation of Embelica Officinalis on Mushroom Nutraceuticals
}

\author{
${ }^{1}$ Poonam Dehariya, ${ }^{2}$ Deepak Vyas \\ ${ }^{1.2}$ Lab of Microbial Technology and Plant Pathology, Department of Botany, Dr HS Gour University, Sagar
} $(M P)$

\begin{abstract}
In present scenario malnutrition is a biggest problem of India. Increasing population and non judicial uses of natural resources have great concern. Present study deals with the production of nutraceuticals from mushroom (Pleurotus sajor-caju (Fr.) Singer) grown on different substrates and enhancement in these nutraceuticals by supplementation of Embelica officinalis. Results reveals that among all the used substrates viz. soybean straw, wheat straw, paddy straw, sunflower stalks, sugarcane bagasses and maize stalks, soybean straw was proved best in terms of nutraceuticals and there was increase in nutritive as well as mineral contents after supplementation. Thus Embelica officinalis should preferred for the supplementation of Pleurotus sajorcaju.
\end{abstract}

Key words: Nutraceutical, Mushroom, Substrates, Supplementation, nutrition.

\section{Introduction:}

The role of dietary active compounds in human nutrition is one of the most important areas of investigation with the findings having wide-ranging implications for consumers, healthcare providers, regulators and industry (Bagchi, 2006). A nutraceutical is any substance that is a food or a part of a food and provides medical or health benefits, including the prevention and treatment of disease. Such products may range from isolated nutrients, dietary supplements and specific diets to genetically engineered designer foods, herbal products, and processed foods such as cereals, soups and beverages (Hardy, 2000).

Oyster mushroom (i.e. Pleurotus spp.) is commonly called as Dhingri in India because of its oyster like shape. Genus Pleurotus belongs to family Tricholomataceae and has about 40 well-recognized species, out of which 12 species are cultivated in different parts of country. Pleurotus is an efficient lignin- degrading mushroom and can grow well on different types of lignocellulolosic materials. Mushroom has been recognized as food contributing to ameliorate the protein malnutrition of the countries which are largely depending upon cereals (Pandey, 2010; Dehariya et al., 2010). Different substrates affected the nutritional composition of mushroom. Protein is one of the most important food factor. The sufficiency of protein in a diet is an important measure of its adequacy and quality (Geda and Joshi, 2006). Minerals in the diet are essential for metabolic reactions, healthy bone formation, transmission of nerve impulses, regulation of water and salt balance (Kalac and Svoboda, 2000).

Mushroom normally ranges between 20 and $40 \%$ protein which is better than many legume sources like soybeans and peanuts, and protein-yielding vegetable foods (Chang and Buswell, 1996; Chang and Mshigeni, 2001). Moreover, mushroom proteins contain all the essential amino acids needed in the human diet and are especially rich in lysine and leucine which are lacking in most staple cereal foods (Chang and Buswell, 1996; Sadler, 2003). Mushrooms are low in total fat content and have a high proportion of polyunsaturated fatty acids (72 to $85 \%$ ) relative to total fat content, mainly due to linoleic acid. The high content of linoleic acids is one of the reasons why mushrooms are considered a health food (Chang and Mshigeni, 2001; Sadler, 2003). Furthermore, they contain significant amounts of carbohydrates and fibers (Crisan and Sands, 1978; Chang and Buswell, 1996). The objective of this study was to determine and compare the nutritive value of oyster mushroom Pleurotus sajor caju cultivated on soybean straw, wheat straw, paddy straw, sunflower stalks, sugarcane bagasses and maize stalks and supplemented with Embelica officinalis.

\section{Materials and Method:}

In the present study Pleurotus sajor-caju was used for the purpose. Pleurotus sajor-caju was cultivated on different conventional substrates viz. Soybean straw, wheat straw, paddy straw, sunflower stalks, sugarcane bagasses, maize straw. For supplementation, powder of Embelica officinalis was used. Supplementation was done at the time of cultivation. The supplementary was properly treated with $25 \mathrm{ppm}$ bavistin (half gram thoroughly mixed with pretreated substrates while spawning).

Preparation of sample: Mushroom samples was prepared by Extraction Technique (Mizuno, 1999). In this method, the mushroom fruiting bodies were first dried at $45-50^{\circ} \mathrm{C}$ in oven for at least one hour and after 
complete dryness were being crushed in a sterile pestle and mortar to form a sharp powder. About $20 \mathrm{gm} / 200$ gm of powder of these mushrooms were taken into $200 \mathrm{ml} / 400 \mathrm{ml}$ of $95 \%$ methanol/ethanol for extraction. The extraction was carried out by a special extraction plant called as Soxhlet extraction Plant. The whole instrument is operated upon electric current and has special staplers to maintain the temperature. The extraction process is carried out for about 16-18 hours in Soxhlet unit at $65{ }^{\circ} \mathrm{C} / 79^{\circ} \mathrm{C}$. After complete extraction, the extract is filtered through whatman number 1 filter paper. The filtered extract was kept in $10-20 \mathrm{ml}$ glass vials and kept in refrigerator or deep freezer at $1-4^{\circ} \mathrm{C}$ for further use.

\section{Analysis of nutrients:}

Protein estimation: The protein content of crude filtrate homogenate was assayed by the method of Lowry et al., (1951), using BSA (bovine serum albumin) as standard. The method was based on the principle that different proteins contain different amount of aromatic residues which react with Folin Cicalteu's Reagent (Phenol reagent) and values are expressed as $\mathrm{mg} / \mathrm{ml}$ of culture filtrate.

Carbohydrade analysis: Using the dinitrisalicylic acid as reagent, $25 \mathrm{~g}$ of 2,5 dinitrisalicylic acid and $75 \mathrm{~g}$ sodium potassium tartrate were dissolved in $50 \mathrm{ml}$ sodium suspension of each of the crushed oven dried mushroom species was added with $1.01 \mathrm{ml}$ of reagent and mixed thoroughly. The mixture boiled in a water bath for ten minutes. After rapid cooling to room temperature, the absorbance was determined at $570 \lambda$ max. The values of component ingredients of carbohydrate determined from a glucose standard curve (AOAC, 1984).

Fat analysis: Mushroom materials were placed on extraction tube. And $1 \mathrm{ml} 0.88 \%$ ammonia solution was added and mixed thoroughly; $10 \mathrm{ml}$ of alcohol was added and mixed to dissolve the protein. The tube was then immersed in boiling water and liberated component fat rose to the surface. When the tube cooled the fat extracted by shaking with 1:1 mixtures of diethyl-ether and petroleum spirit $(20 \mathrm{ml})$. The bulked solution was distilled from the extract and sample dried and weighed to determine weight and fat components (AOAC, 1984).

Minerals analysis: An aliquots of the digest was taken for determination of $\mathrm{Ca}, \mathrm{Na}, \mathrm{K}, \mathrm{P}$ and $\mathrm{Mg}$ using spectronic at $430 \lambda \max$ and EDTA complex metric titrations, these minerals were determined by flame emission after appropriate dilution, using a plan photometer equipped with optical filter (AOAC, 1984).

Crude fiber determination: Crude fiber was determined using a Hennenberg- Stohmann method. A $2 \mathrm{~g}$ sample from mushroom species was boiled in antifoaming solution (1-octanol) for $30 \mathrm{~min}$. Pyrex glasses were used to filter the solution where the residues were thoroughly washed with boiling water (3 times) to remove hydrochloric acid. The Pyrex glasses containing the residues were dried at $100^{\circ} \mathrm{C}$ for five hours, cooled to room temperature and then weighed. The crucibles were then placed in a muffle furnace at $555^{\circ} \mathrm{C}$ for $5 \mathrm{hrs}$. cooled to room temperature and then reweighed to find the fiber content percentage.

Moisture content determination: A $2 \mathrm{~g}$ sample from each of the mushroom sp. used in the study was oven dried at $105^{\circ} \mathrm{C}$ to constant weights. The difference between the weight of the sample before drying and after drying was used to calculate the percentage moisture content (Masamba and Kazombo-Mwale, 2010).

Ash determination: A $2 \mathrm{~g}$ sample from the finally ground mushroom was placed in a crucible and converted into ash at $550-600^{\circ} \mathrm{C}$ for $5 \mathrm{hrs}$. in a carbolite muffle furnace after which it was allowed to cool in a dessicator. The difference in the weight of the crucible without the sample before and after ashing was used to calculate the ash content (Masamba and Kazombo-Mwale, 2010).

\section{Result and discussion:}

The Protein, fat, carbohydrate, crude fiber, moisture and ash contents of mature fruiting bodies of Pleurotus sajor caju cultivated on different lignocellulosic substrates alone and in supplementation with Embelica officinalis are shown in Table 1 and 2. Table 1 shows that $P$. sajor caju fruiting bodies produced on soybean straw possessed the highest protein content of $29.5 \%$ on a dry weight basis followed by sunflower stalks $(29.0 \%)$, wheat straw $(28.0 \%)$, maize stalks $(27.5 \%)$ and paddy straw $(26.16 \%)$. Least protein contents was found in sugarcane bagasses $(25.5 \%)$. The fat content of P. sajor caju was $2.69 \%$ grown on sunflower stalks being the highest followed by paddy straw (2.62\%), sugar cane bagasses (2.54), wheat straw (2.53\%), soybean straw (2.48\%) and least in maize stalks $(1.89 \%)$. The $\%$ of protein and fat content were similar as reported in earlier studies (Patil et al., 2008, Patil and Dakore, 2007).

Maximum Carbohydrate content of $P$. sajor caju was $56.36 \%$ in fruiting bodies cultivated on soybean straw straw whereas least was $53.87 \%$ cultivated on paddy straw. The highest crude fiber was obtained on soybean straw $(7.77 \%)$ followed by paddy straw $(7.67 \%)$, sunflower stalks and wheat straw $(7.70 \%)$, sugarcane bagasses $(7.58 \%)$ and least in maize stalks $(7.39 \%)$. These results were confirmed with findings of Bonatti et 
al. (2004), Khyadagi et al., (1998), (Sharma \& Madan 1993), Singh et. al.(2003). From the present study it is evident that, Pleurotus sajor caju is the suitable species for nutritional contents. The protein contents of various lignocellulosic residues were compared and it was reported that the nitrogen content in fruiting bodies was higher in leguminous plant substrates than non-leguminous ones (Sharma \& Madan, 1993). These results were confirmed with the findings of Kadlag et al., (1998) Mandhare (2000). The protein content usually ranges between $20-30 \%$ on a dry weight basis. The maximum ash content of $P$. sajor caju was found when grown on sugarcane bagasses $(6.52 \%)$ followed by mushroom grown soybean straw $(6.39 \%)$, paddy straw $(6.28 \%)$, and least in maize stalks and sunflower stalks (6.18\%). Similar results were reported by El -Kattan et al., (1991).

Table 2 shows the nutritive content of $P$. sajor-caju on different lignocellulosic substrates supplemented with Emblica officinalis. Maximum protein (29.5\%) reported from soybean straw and minimum $(25.5 \%)$ from sugarcane bagasses. Minimum carbohydrate $(50.1 \%)$ reported from paddy straw and maximum (56.3\%) from soybean straw. Fat content reported $1.90 \%$ to $2.70 \%$. Moisture content reported $88.3 \%$ to $90.2 \%$ and ash from $6.4 \%$ to $7.9 \%$. Maximum fiber content (7.9\%) from soy bean straw and sunflower stalks and minimum (7.4\%) from maize stalks.

The $\mathrm{Ca}, \mathrm{K}, \mathrm{Na}, \mathrm{Mg}, \mathrm{P}$ and Fe contents of mature fruiting bodies of Pleurotus sajor caju cultivated on different lignocellulosic substrates alone and in supplementation with Embelica officinalis are shown in Table 3 and 4. Table 3 shows that $P$. sajor caju fruiting bodies produced on soybean straw possessed the highest $\mathrm{Ca}$ (308.4) followed by sunflower stalks (300.0) and minimum (270.0) on wheat straw. Potassium (K) content was higher compared to other minerals in P. sajor-caju. The quantity of $\mathrm{K}$ was recorded from 1900 to $2687 \mathrm{mg} / 100 \mathrm{~g}$. The highest value was recorded when cultivated on soybean straw $(2687 \mathrm{mg} / 100 \mathrm{~g})$ followed by the cultivation on paddy straw $(2650 \mathrm{mg} / 100 \mathrm{~g})$ and the least was recorded on the maize stalks $(1900 \mathrm{mg} / 100 \mathrm{~g})$. Sodium concentration varied significantly with different substrates. The highest sodium concentration was recorded on soybean straw $(308.4 \mathrm{mg} / 100 \mathrm{~g})$ and minimum was obtained on maize stalks $(279.0 \mathrm{mg} / 100 \mathrm{~g})$. The highest magnesium concentration was recorded on sunflower stalks $(157.4 \mathrm{mg} / 100 \mathrm{~g})$ and minimum was obtained on maize stalks and paddy straw $(151.4 \mathrm{mg} / 100 \mathrm{~g})$. Maximum phosphorus content of $1000 \mathrm{mg} / 100 \mathrm{~g}$ was recorded on soybean straw and minimum was obtained on maize stalks $(800.0 \mathrm{mg} / 100 \mathrm{~g})$. Same results were obtained in case of iron content. Maximum iron content of $130 \mathrm{mg} / 100 \mathrm{~g}$ was recorded on soybean straw and minimum was obtained on maize stalks $(100.0 \mathrm{mg} / 100 \mathrm{~g})$. These results coinced with those observed by Kikuchi et al., (1884), Rathor and Thakore (2004), (Caglarirmak, 2007) (Patil et al., 2010).

Table 4 shows the mineral contents of $P$. sajor-caju on different lignocellulosic substrates supplemented with Embelica officinalis. Maximum Ca (308.4) reported from sunflower stalks (315.0) and minimum (274.3) from wheat straw. The highest potassium content was recorded when cultivated on soybean straw $(2689.7 \mathrm{mg} / 100 \mathrm{~g})$ followed by the cultivation on paddy straw $(2689.0 \mathrm{mg} / 100 \mathrm{~g})$ and the least was recorded on the maize stalks $(1946.7 \mathrm{mg} / 100 \mathrm{~g})$. The highest sodium concentration was recorded on soybean straw $(341.7 \mathrm{mg} / 100 \mathrm{~g})$ and minimum was obtained on maize stalks $(284.0 \mathrm{mg} / 100 \mathrm{~g})$. The highest magnesium concentration was recorded on sunflower stalks $(159.7 \mathrm{mg} / 100 \mathrm{~g})$ and minimum was obtained on maize stalks $(154.0 \mathrm{mg} / 100 \mathrm{~g})$. Maximum phosphorus content of $1096.7 \mathrm{mg} / 100 \mathrm{~g}$ was recorded on soybean straw and minimum was obtained on maize stalks $(810.0 \mathrm{mg} / 100 \mathrm{~g})$. Maximum iron content of $130 \mathrm{mg} / 100 \mathrm{~g}$ was recorded on soybean straw and minimum was obtained on maize stalks $(100.0 \mathrm{mg} / 100 \mathrm{~g})$.

When we compare table 2 with table 1 , it is clearly evident from the data that after supplementation all the substrates shows increase in amount and same results obtained when table 4 compared with table 3.Thus supplementation of Embelica officinalis was proved better for enhancement in the amount of nutraceuticals.

\section{Observation:}

Table: 1 Nutritive content of $P$. sajor-caju on different substrates.

\begin{tabular}{|l|c|c|c|c|c|c|}
\hline Substrates & $\begin{array}{c}\text { Protein } \\
(\%)\end{array}$ & $\begin{array}{c}\text { Carbohydrate } \\
(\%)\end{array}$ & $\begin{array}{c}\text { Fat } \\
(\%)\end{array}$ & $\begin{array}{c}\text { Moisture } \\
(\%)\end{array}$ & $\begin{array}{c}\text { Ash } \\
(\%)\end{array}$ & $\begin{array}{c}\text { Fiber } \\
(\%)\end{array}$ \\
\hline Soybean straw & 29.5 & 56.36 & 2.48 & 90.89 & 6.52 & 7.77 \\
\hline Wheat straw & 28.0 & 55.46 & 2.53 & 86.23 & 6.39 & 7.70 \\
\hline Paddy straw & 26.16 & 35.25 & 2.62 & 90.13 & 6.28 & 7.67 \\
\hline Sun flower stalks & 29.0 & 54.0 & 2.69 & 86.26 & 6.18 & 7.70 \\
\hline $\begin{array}{l}\text { Sugarcane } \\
\text { bagasses }\end{array}$ & 25.5 & 49.76 & 2.54 & 85.13 & 6.31 & 7.58 \\
\hline Maize stalks & 27.5 & 50.80 & 1.89 & 88.23 & 6.18 & 7.39 \\
\hline CD (0.05\%) & 0.85 & 0.89 & 0.52 & 0.28 & 0.05 & 0.07 \\
\hline S Em $( \pm)$ & 0.27 & 0.29 & 0.17 & 0.09 & 0.01 & 0.02 \\
\hline
\end{tabular}

Values are given in average of three replicates 
Effect Of Supplementation Of Embelica Officinalis On Mushroom Nutraceuticals

Table: 2 Nutritive content of $\boldsymbol{P}$. sajor-caju on different lignocellulosic substrates supplemented with Emblica officinalis:

\begin{tabular}{|l|l|l|l|l|l|l|}
\hline Substrates & $\begin{array}{l}\text { Protein } \\
(\%)\end{array}$ & $\begin{array}{l}\text { Carbohydrate } \\
(\%)\end{array}$ & $\begin{array}{l}\text { Fat } \\
(\%)\end{array}$ & $\begin{array}{l}\text { Moisture } \\
(\%)\end{array}$ & $\begin{array}{l}\text { Ash } \\
(\%)\end{array}$ & $\begin{array}{l}\text { Fibre } \\
(\%)\end{array}$ \\
\hline SS & 29.5 & 56.3 & 2.48 & 90.0 & 6.7 & 7.9 \\
\hline WS & 28.2 & 55.6 & 2.53 & 86.6 & 6.6 & 7.8 \\
\hline PS & 26.5 & 50.4 & 2.63 & 90.2 & 6.4 & 7.8 \\
\hline SB & 25.5 & 50.1 & 2.54 & 88.4 & 7.7 & 7.7 \\
\hline MS & 27.7 & 51.0 & 1.90 & 85.3 & 7.9 & 7.4 \\
\hline SFS & 29.1 & 54.7 & 2.70 & 88.3 & 7.8 & 7.9 \\
\hline CD $(\mathbf{0 . 0 5 \% )}$ & $\mathbf{0 . 6 3}$ & $\mathbf{0 . 5 0}$ & $\mathbf{0 . 5 3}$ & $\mathbf{0 . 3 0}$ & $\mathbf{0 . 3 4}$ & $\mathbf{1 7 . 5 3}$ \\
\hline S Em $( \pm)$ & $\mathbf{0 . 2 0}$ & $\mathbf{0 . 1 6}$ & $\mathbf{1 . 7 2}$ & $\mathbf{0 . 1}$ & $\mathbf{0 . 1 1}$ & $\mathbf{5 . 6 9}$ \\
\hline
\end{tabular}

Values are given in average of three replicates

Table: 3 Mineral contents of $P$. sajor-caju on different lignocellulosic substrates.

\begin{tabular}{|l|c|c|c|c|c|c|}
\hline Substrates & $\begin{array}{c}\text { Ca } \\
(\mathbf{m g} / \mathbf{1 0 0 g})\end{array}$ & $\begin{array}{c}\mathbf{K} \\
(\mathbf{m g} / \mathbf{1 0 0 g})\end{array}$ & $\begin{array}{c}\text { Na } \\
(\mathbf{m g} / \mathbf{1 0 0 g})\end{array}$ & $\begin{array}{c}\mathbf{M g} \\
(\mathbf{m g} / \mathbf{1 0 0 g})\end{array}$ & $\begin{array}{c}\mathbf{P} \\
(\mathbf{m g} / \mathbf{1 0 0 g})\end{array}$ & $\begin{array}{c}\text { Fe } \\
(\mathbf{m g} / \mathbf{1 0 0 g})\end{array}$ \\
\hline SS & 308.33 & 2687 & 308.4 & 156.4 & 1000 & 130.0 \\
\hline WS & 270.0 & 2650 & 300.0 & 157.0 & 800.7 & 108.4 \\
\hline PS & 292.7 & 2266.7 & 290.0 & 151.4 & 915.0 & 120.0 \\
\hline SFS & 300.0 & 2320 & 299.4 & 157.4 & 897.4 & 110.0 \\
\hline SB & 275.0 & 2071.7 & 282.4 & 152.7 & 874.0 & 120.0 \\
\hline MS & 292.4 & 1900 & 279.0 & 151.4 & 800.0 & 100.0 \\
\hline CD (0.05\%) & 13.98 & 56.23 & 10.03 & 4.39 & 11.72 & 16.50 \\
\hline S Em $( \pm)$ & 4.53 & 18.25 & 3.25 & 1.42 & 3.80 & 5.35 \\
\hline
\end{tabular}

Values are given in average of three replicates

Table: 4: Mineral contents of $\boldsymbol{P}$. sajor-caju on different lignocellulosic substrates supplemented with Emblica officinalis.

\begin{tabular}{|l|c|c|c|c|c|c|}
\hline Substrates & $\begin{array}{c}\text { Ca } \\
(\mathbf{m g} / \mathbf{1 0 0 g})\end{array}$ & $\begin{array}{c}\mathbf{K} \\
(\mathbf{m g} / \mathbf{1 0 0 g})\end{array}$ & $\begin{array}{c}\mathbf{N a} \\
(\mathbf{m g} / \mathbf{1 0 0 g})\end{array}$ & $\begin{array}{c}\mathbf{M g} \\
(\mathbf{m g} / \mathbf{1 0 0 g})\end{array}$ & $\begin{array}{c}\mathbf{P} \\
(\mathbf{m g} / \mathbf{1 0 0 g})\end{array}$ & $\begin{array}{c}\text { Fe } \\
(\mathbf{m g} / \mathbf{1 0 0 g})\end{array}$ \\
\hline SS & 311 & 2689.7 & 341.7 & 157.0 & 1096.7 & 130.0 \\
\hline WS & 274.3 & 2663.4 & 316.7 & 156.0 & 908.0 & 126.7 \\
\hline PS & 295.3 & 2269.0 & 301.7 & 156.7 & 925.0 & 111.7 \\
\hline SB & 281.7 & 2079.4 & 200.0 & 158.4 & 888.4 & 111.7 \\
\hline MS & 305.4 & 1946.7 & 284.0 & 154.0 & 810.0 & 110.0 \\
\hline SFS & 315.0 & 2356.7 & 323.4 & 159.7 & 821.7 & 128.4 \\
\hline $\begin{array}{l}\text { CD } \\
(\mathbf{0 . 0 5 \%})\end{array}$ & $\mathbf{9 . 0 5}$ & $\mathbf{4 0 . 1 5}$ & $\mathbf{3 5 . 5 9}$ & $\mathbf{3 . 9 7}$ & $\mathbf{7 0 . 9 9}$ & $\mathbf{1 7 . 5 3}$ \\
\hline S Em $( \pm)$ & $\mathbf{2 . 9 3}$ & $\mathbf{1 3 . 0 3}$ & $\mathbf{1 1 . 5 5}$ & $\mathbf{1 . 2 9}$ & $\mathbf{2 3 . 0 4}$ & $\mathbf{5 . 6 9}$ \\
\hline
\end{tabular}

Values are given in average of three replicates

\section{References:}

[1] Bagchi D. Nutraceuticals and functional foods regulations in the United States and around the world. Toxicology 2006; 221(1):1-3.

[2] Hardy G. Nutraceuticals and functional foods: introduction and meaning. Nutrition 2000; 16(7-8): 688-689.

[3] The Health \& Wellness Foods Industry in India: An Overview. Tata Strategic Management Group. Osaka International Business Promotion Center. 2009.

[4] Palthur MP, Palthur SSS, Chitta SK Nutraceutical: Concept and regulatory scenario. International journal of pharmacy and pharmaceutical sciences. 2010; 2: 14-20.

[5] Mizuno, T. (1999). Bioactive Substances in Hericium erinaceus (Bull; Fr.) Press. (Yamabushitake), and its medicinal Utilization. Int. J. of Med. Mush. 1: 105-119.

[6] Lowry OH, Rosebrough NJ, Farr AL, Randall, R.J Protein measurement with folin phenol reagents. J. Biol. Chem. 1951; 193: 265275.

[7] Association of official Agricultural Chemist (AOAC), $6^{\text {th }}$ Edition, Washington DC, Longman Group Limited, $1984 ; 153$.

[8] Masamba KG, Kazombo-Mwale R Determination and comparison of nutrient and mineral contents between cultivated and indigenous edible mushrooms in Central Malawi. African Journal of Food Science 2010; 4: 176-179.

[9] Dehariya, P., Chaubey, A. and Vyas, D. (2010). Mushrooms: A nutritive food for human beings. Microbial biotech. and Ecology (Eds: D. Vyas, N. Khare, A.K. Pandey) pp.344-352. Daya Publication New Delhi.

[10] Pandey, A. K. (2010). Mushroom Biodiversity: A natural remedy for malnutrition in India (Abst.) National Seminar on Role of 
Biodiversity in sustainable agriculture (Jhansi). March 4-5 pp 72-73.

[11] Geda, A.K. and Joshi, P. K. (2006). Nutritional qualities of Mushrooms. Compandium of lectures-Emerging Areas in Mushroom Diversity, Production and post Harvest Developments. pp 53-68.

[12] Sueli, OS, Sandra, MG C, \& Edmar, C Chemical composition of Pleurotus pulmonarious (Fr.) Quel., Substrates and Residue after Cultivation. Brazilian Archives of Biology and Technology. 2002; 45: 531-535.

[13] Wang, D., Sakoda, A., and Suzuki, M. (2001). Biological efficiency and nutritional value of oyster mushroom cultivated on spent beet grain. Bioresource technology.78: 293-300.

[14] Miles PG, Chang ST Mushroom Biology Concise Basics and Current Developments. World Scientific Publishing Co. Pvt. Ltd. 1997; 105-106.

[15] Chang, S.T., Lau, O.W. and Cho, K.Y. (1981). The cultivation and nutritional value of Pleuorotus sajor-caju. European J. Appl. Microbiol. Biotechnol. 12: 58-62

[16] Patil SS, Ahmed SA, Telang SM, Baig MMV The nutritional value of Pleurotus ostreatus (Jaco:Fr.) Kumm Cultivation on different lignocellulosic agro wastes. Innovative Romanian Food Technology 2010; 7: 66-76

[17] Kalac, P.,\& Svoboda, L. (2000). A review of trace element concentrations in edible mushrooms. Food Chemistry, 69, $273-281$.

[18] Chang ST, Buswell JA (1996). Mushroom nutriceuticals. World J. Microb. Biotechnol. 12: 473-476.

[19] Chang ST, Mshigeni KE (2001). Mushroom and their human health: their growing significance as potent dietary supplements. The University of Namibia, Windhoek, 1-79: 1188-1194.

[20] Sadler M (2003). Nutritional properties of edible fungi. Br. Nutr. Found. Nutr. Bull. 28: 305-308

[21] Crisan EV, Sands A (1978). Nutritional value. In: Chang ST, Hayes WA (Eds). The Biology and Cultivation of Edible Mushrooms. London, Academic Press Inc, pp. 137-165.

[22] Patil, S. S. and Dakore, H. G. Comparative study on yield performance and Nutritive value of oyster mushroom on soybean straw. Bioinfolet, 2007; 4(1): 57-59.

[23] Patill S.S., Kadam R.M. Shinde S.L. and Deshmukh S.A. Effect of different substrate on productivity and proximate composition of P. florida. Int. J. Plant Sci. 2008; 3(1): 151-153.

[24] Bonatti, M., Karnopp, P., Soares, H.M., Furlan, S.A. Evaluation of Pleurotus ostreatus and Pleurotus sajor-caju nutritional characteristics when cultivated in different lignocellulosic wastes. Food Chem., 2004; 88(3): 425-428.

[25] Khydagi, K.S.; Sharda, G.S. and Meera Rao. Proximate composition of Oyster mushroom. Karnataka J. Agri. Sci. 1998 ; 11 (2): $548-549$.

[26] Sharma, S. \& Madan, M. Microbial protein from leguminous and non-leguminous substrates. Acta Biotechnologica. 1993; 13: $131-139$.

[27] Mandhare, V.K. "Productivity of Pleurotus sp. On different substrates and its effect on Nutritional Indices of spent straw. Ph.D. Thesis. Marathwada Agricultural Univ., Parbhani. 2000.

[28] El - Kattan, M.H.; Helmy, Z.A.; Abdel, H.; El - Leithy, M. and Abdelkawi, K.A. Studies on cultivation techniques and Chemical composition of Oyster mushrooms. Mushroom. J. for tropics. 1991; 11 (314): 59 - 66.

[29] Kikuchi, M., Tamakawa, K., Hiroshima, K., Aihara, Y., Mishima, Y., Seki, T., Tsunoda, A. Survey on contents of metals in edible mushrooms. Journal of the Food Hygienic Society of Japan. 1984; 25(6) 534-542.

[30] Rathore, V. R. S., and Thakore, B. B. L. Effect of different substrates on the production and nutritional value of sporophores of Pleurotus florida (Eger) Nom. Nud. Journal of Mycology and Plant Pathology, 2004; 34( 1): 66-68.

[31] Çağlarırmak, Necla. The nutrients of exotic mushrooms (Lentinula edodes and Pleurotus species) and an estimated approach to the volatile compounds. Food Chemistry. 2007; 105(3): 1188-1194.

[32] Patil SS, Ahmed SA, Telang SM, Baig MMV The nutritional value of Pleurotus ostreatus (Jaco:Fr.) Kumm Cultivation on different lignocellulosic agro wastes. Innovative Romanian Food Technology 2010; 7: 66-76

[33] Ahmed, SA, Kadam1, J.A.,. Mane, V.P. Patil S.S and Baig, M.M.V. Biological Efficiency And Nutritional Contents Of Pleurotus florida (Mont.) Singer Cultivated On Different Agro-wastes. Nature and Science, 2009;7(1), ISSN 1545-0740 